\title{
A Case for Regulating Corporate Governance for SMEs in Ghana
}

\author{
Benjamin A. Asunka ${ }^{1}$ \\ ${ }^{1}$ School of Business and Management Studies, Bolgatanga Polytechnic, Bolgatanga, Ghana \\ Correspondence: Benjamin A. Asunka, Bolgatanga Polytechnic, Box 767, Bolgatanga, Upper East Region, \\ Ghana. E-mail: benasunka@gmail.com \\ Received: January 6, 2017 \\ Accepted: March 2, 2017 \\ Online Published: March 26, 2017 \\ doi:10.5539/ijbm.v12n4p168 \\ URL: https://doi.org/10.5539/ijbm.v12n4p168
}

\begin{abstract}
Small and Medium-Scale Enterprises (SMEs) are an integral part of every nation's economic activity. They play an important role in nation building. It is believed that as they grow and expand the economy also grows. Corporate governance involves the systems and processes that are put in place to promote accountability and compliance by organizations to ensure value is created for the owners of the investment. Unfortunately, SMEs in Ghana have been left out of the corporate governance idea, because all the regulations and code of best practices on corporate governance concern mostly large corporate bodies and listed firms. With all the challenges that SMEs are faced with, the researcher tries to make a strong case for the regulation of corporate governance specifically for these SMEs to ensure they are better managed.

Adopting the literature review method, the researcher reviewed various publications about the challenges that SMEs face in Ghana. Various researchers in this subject matter have established a lot of challenges faced by SMEs, these challenges exist in both the internal and external environments of these businesses. The author is of the opinion that most of the internal challenges are a result of corporate governance lapses, and if these lapses are addressed properly, it would help mitigate the challenges that emanate from the external environment. The recommendation therefore, is that a code of corporate governance for SMEs is necessary to help sustain their survival and growth.
\end{abstract}

Keywords: corporate governance, Ghana, SMEs, SME challenges

\section{Introduction}

Small and Medium-Scale Enterprises (SMEs) are an integral part of every nation's economic activity. They play an important role in nation building. It is believed that as they grow and expand the economy also grows. SMEs create employment, and serve as a major tool for poverty alleviation and economic development (Adjei, Oteng, \& Fianu, 2014). Small and Medium-Scale Enterprises are enterprises that employ relatively small financial and human capital to do businesses of all kinds. In Ghana, owner-managers find it easier to engage in trade businesses than the other forms of businesses. There is growing recognition of the important role SMEs play in economic development.

Small Businesses are often found in the sector of trade and commerce, agriculture, ICT, education, health, manufacturing, production, and other service industries. Under the Venture Capital Trust Fund Act, 2004 (Act 680), Small and Medium-Scale Enterprises are characterized as an industry, project undertaking or economic activity whose total asset base, excluding land and building does not exceed the cedi equivalent of US\$1 million in value.

In some developed industrial economies, SMEs sector is the largest employer of workers, and the interest in the role of SMEs in the development process continues to be in the forefront of policy debates in most countries. Governments at all levels have undertaken initiatives to promote the growth of SMEs (Carsamer, 2009).

Ntim, Oteng, and Fianu, (2014) stated that there is growing recognition of the important role small and medium scale enterprises (SMEs) play in the economic development of most countries. They are often described as efficient and prolific job creators, the seeds of big businesses and the fuel of national economic engines. It is argued that SMEs are particularly important in supporting economic growth and livelihoods in developing countries. Even in the developed economies, the SME sector is the largest employer of workers. Small enterprises have been noted to contribute about 85 per cent of manufacturing employment (Steel and Webster, 1991) and account for about 92 per cent of businesses in Ghana (Abor \& Adjasi, 2007). SMEs in Ghana have an 
important role to play in spurring economic growth given that they represent a vast portion of the firm tissue in the economy. The Department of Economic Development of Dubai reports that the small and medium enterprises (SMEs) sector of Dubai comprises $95 \%$ of the businesses, $42 \%$ of the workforce and contributes to $40 \%$ of value added to the Dubai Economy. SMEs are the backbone of the EU economy - they represent $99 \%$ of all enterprises in the EU. Some 23 million SMEs provide around 75 million jobs (European Commission, 2005), and in the UK, SMEs account for 99.9 per cent of all private sector businesses in the UK and 59.3 per cent of private sector employment.

The Securities and Exchange Commission (SEC) of Ghana defines Corporate Governance as the manner in which corporate bodies are managed and operated. Corporate Governance can be described as the mechanisms and procedures by which control, checks and balances are imposed on the internal management and its stewardship of company resources in order to ensure transparency, accountability, efficiency and maximization of shareholders investments. Corporate Governance systems have evolved over centuries, mainly due to corporate failures that have been recorded over the years. Probably the first well-documented failure of governance was the South Sea bubble1 in the 1700s, which revolutionized business law and practices in England. However, the subject of corporate governance in many other developed markets in the late 1900's received serious attention after some corporate and business collapses such as Parmalat and Enron cases which are attributed to poor governance practices. This development was accelerated with the onset of the Asian crisis in mid-1997 and the early 2000 global financial crisis that started out in the US housing market, causing global economic contagion (Ghana SEC, 2002).

Attempts have been made in the past in Ghana to promote effective corporate governance through various regulations. Basically, the Ghanaian regulatory framework with regard to corporate governance comprises the Ghana's companies code (1963), the Securities Industry Law, 1993 (PNDCL333), the Membership and Listing Regulations of the Ghana stock exchange (GSE, 1990). Ghana also adopted the International Financial Reporting Standards in 2007, which replaced the then Ghana Accounting Standards that was in place since 2003, the latter was finally phased out in December 2009. Other laws that were enacted to ensure effective corporate governance in the public sector of Ghana include the Financial Administration Act, 2003 (Act 654), the Internal Audit Agency Act 2003, Act (658), And the Public Procurement Act 2003, (Act 663).

There are also a number of corporations that have been established to help advance corporate governance in Ghana. These include the Ghana Audit Service, and the Securities and Exchange Commission which developed a Corporate Governance Code of Best Practice to be followed by the companies' code in Ghana (Tsamenyi, Enninful, \& Onumah, 2007). Thus, the SEC Guidelines on Best Corporate Governance Practices is based on the Organization for Economic Corporation and Development (OECD) principles. The Bank of Ghana (BoG) also incorporated some corporate governance rules into the Banking Act, 2004 (Banking Act 2004 amended in 2007) and published the BoG code of Conduct for Primary Dealers (ROSC, 2005).

The lack of proper governance mechanisms have been attributed for the failure of state owned enterprises in Ghana. This phenomenon may well cripple the effective development and growth of SMEs as well in Ghana. It is important then for proper management of this sector to ensure enhanced performance. Even though there is evidence of legislation and proposed principles of Corporate Governance in Ghana, they all tend to focus on listed firms and big private companies; none has been consciously formulated to meet the needs of SMEs in Ghana. This paper aims to make a strong case for the need for a code of best practice of Corporate Governance for SMEs in Ghana, by reviewing empirical literature on challenges faced by SMEs. It then goes on to examine how those challenges relate to corporate governance, and suggests how a code of best practice can help to sustain and grow SMEs in Ghana.

\section{Review of Relevant Literature}

\subsection{Small and Medium Scale Enterprises (SMEs)}

There is no universal definition of SMEs. Countries have used various criterions to define SMEs. Some countries use turnover of the company to determine the size of an enterprise, whereas some use fixed investment or the number of employees (Lokhande, 2011), sales volume, and worth of assets (Rahman, 2001). The Ghana Statistical Service (GSS) defines SMEs as enterprises that employ less than 10 persons while those that employ more than 10 people are classified as Medium and Large Scale Enterprises. Alternatively, the National Board for Small Scale Industries (NBSSI) in Ghana combines both the fixed asset and number of employees' criteria to define Small and Medium Scale Enterprises. Thus small enterprises employ between six and 29 people or with fixed assets not exceeding US\$100,000 excluding land and building. However, those with between 30 and 100 employees are classified as medium sized firms. 
Small and Medium-Scale Enterprises (SMEs) are an integral part of every nation's economic activity. They play an important role in nation building. It is believed that as they grow and expand the economy also grows. SMEs create employment, and serve as a major tool for poverty alleviation and economic development (Adjei et al., 2014). Though there are many arguments on the overall contribution of small businesses in the new employment, it is considered as an important source for employment creation (Curran, 2000). Baumol (2004) suggests that small entrepreneurial organizations and entrepreneurs will always be considered important for growth of developing economies.

Small enterprises in Ghana are said to be a characteristic feature of the production landscape and have been noted to provide about $85 \%$ of manufacturing employment of Ghana (Aryeetey, 2001). SMEs are also believed to contribute about $70 \%$ to Ghana's GDP and account for about $92 \%$ of businesses in Ghana. SMEs therefore having a crucial role to play in stimulating growth, generating employment and contributing to poverty alleviation, given their economic weight in African countries. SME ${ }^{\text {ee }}$ forms a huge chunk of businesses in both the formal and the informal sector. Whilst SMEs in developed countries make a significant contribution to GDP and national employment, there is not sufficient data to say the same about SME's in Ghana (Culkin \& Smith, 2000).

A recent policy to promote the growth of SMEs in Ghana was contained in the 2005 report of the second Growth and Poverty Reduction Strategy (GPRS II 2006 - 2009) now Ghana Shared Growth Development Agenda, 2010-2013 framework. The goal of this policy was to engender sufficient economic growth that will propel Ghana into a middle-income economy by 2015. According to a report from the OECD (2006), the SME sector was showing positive signs of response to this reform. The World Bank/IMFecs annual Doing Business Report (2008) has ranked Ghana as a top ten (10) global reformer for two years in a row (2006 and 2007). In addition, Ghana's economic policy on business models has been geared towards divestiture of state-owned enterprises and more of private ownership.

\subsection{Corporate Governance for SMEs}

The definition of corporate governance most widely used is "the system by which companies are directed and controlled" (Cadbury Committee, 1992). "Corporate governance involves a set of relationships between a company's management, its board, its shareholders and other stakeholders. Corporate governance also provides the structure through which the objectives of the company are set, and the means of attaining those objectives and monitoring performance are determined" (The OECD, 2004).

Jill and Aris (2010, p. 14) noted that some of the widely used definitions of corporate governance are rather narrow in perspective. They suggest that "Corporate Governance is the system of checks and balances, both internal and external to companies, which ensures that companies discharge their accountability to all their stakeholders and act in a socially responsible way in all areas of their business activity. The concept of corporate governance is to enable firms function more effectively by promoting accountability and compliance. Various structures are put in place internally to serve as checks and balances are placed on directors and key functionaries to guide decision making and business transactions. It is believed that the Asian crisis and the relative poor performance of the corporate sector in Africa have made the issue of corporate governance a catchphrase in the development debate (Berglof \& von Thadden, 1999).

Poorly governed firms are expected to be less profitably, have more bankruptcy risks, lower valuations and pay out less to their shareholders, while well-governed firms are expected to have higher profits, less bankruptcy risks, higher valuations and pay out more cash to their shareholders (Kyereboah-Coleman \& Biekpe, 2015). Claessens (2003) also argues that better corporate frameworks benefit firms through greater access to financing, lower cost of capital, better performance and more favourable treatment of all stakeholders. The position has been stated that, weak corporate governance does not only lead to poor firm performance and risky financing patterns, but are also conducive to macroeconomic crises like the 1997 East Asia crisis. Other researchers contend that good corporate governance is important for increasing investor confidence and market liquidity (Donaldson, 2003).

In some parts of the world there have been efforts to propose guidelines for corporate governance for SMEs. There is no universally approved standard model of corporate governance for SMEs. Nevertheless, there are sources of guidance to which SMEs and their advisers can turn (ACCA, 2015). The European Confederation of Directors Associations (ecoDa) has issued Corporate Governance Guidance and Principles for Unlisted Companies in Europe, designed to be a practical tool for businesses and their stakeholders (ecoDa 2010). Though developed with European companies in mind, the guidance and principles also have relevance to 
businesses in other regions. As ecoDa (2010) notes, good corporate governance for unlisted companies is about 'establishing a framework of company processes and attitudes that add value to the business, help build its reputation and ensure its long-term continuity and success'.

In the UK, the Quoted Companies Alliance (QCA) has developed a code with smaller listed companies in mind, Corporate Governance Code for Small and Mid-Size Companies (QCA 2013). The UK's Institute of Directors has also offered guidance in the form of Corporate Governance Guidance and Principles for Unlisted Companies in the UK (IoD 2010). The British Standards Institute has published a standard on governance designed to be applicable by any type and size of entity, its Code of Practice for Delivering Effective Governance of Organizations'.

Elsewhere in the world similar efforts have been made, such as The Corporate Governance Code for Small and Medium Enterprises: Building the Foundations for Growth and Sustainability in Dubai (SME Dubai and Hawkamah) and Guidelines on Corporate Governance for SMEs in Hong Kong (Hong Kong Institute of Directors 2014). The International Finance Corporation (IFC), the largest global development institution focusing exclusively on the private sector in developing countries, has issued its own IFC Family Business Governance Handbook (IFC 2011).

Regardless of the size of the SME, the corporate governance practices can apply to all. "Overall, corporate governance is no longer limited to leading companies in fact many small organizations are slowly integrating these techniques to create a sound governance framework (Maharaj, 2011). In a recent Corporate Governance for Small Business Report compiled by 4imprint, a company that provides in-depth, how-to articles based on research conducted by professionals and published experts who are familiar with industry trends- points out that small enterprises should start integrating corporate governance practices to best support its investors or multiple business partners.

Bundaleska, Dimitrova and Nikolovska (2011) suggest some policies and procedures that are advisable to small and medium businesses are as follows; a code of conduct $\&$ ethics, procedures for monitoring transactions with affiliated/connected entities (including relevant reports), procedures for identifying possible conflicts of interest and acting accordingly, transparency and disclosure procedures, and whistle blowing procedures. Dube, Dube, and Mishra. (2011) also propose corporate governance norms for SMEs as follows:
A. Prepare and Publish 'Mission Statement' of Enterprises
B. Enterprise Policy Statement to Manage Business Growth
C. Enterprise Succession Plan
D. Annual Management and Accomplishment Statements

E. Management Structure and Level of Professional Qualification relevant to Industry

F. Method of Accounting and Disclosure of Audited Account

G. Stakeholder Relations and Welfare undertaken by the enterprise

H. Legal and Regulatory Compliance

Dube et al. (2011) are of the opinion that business prosperity cannot be commanded. People, teamwork, leadership, enterprise, experience and skills are what really produce prosperity. There is no single formula to weld these together, and it is dangerous to encourage the belief that rules and regulations about structure will deliver success. Accountability by contrast does require appropriate rules and regulations, in which disclosure is the most important element. Good governance ensures that constituencies (stakeholders) with a relevant interest in the company's business are fully taken into account. Good corporate governance is not just a matter of prescribing particular corporate structures and complying with a number of hard and fast rules. There is a need for broad principles. All concerned should then apply these flexibly and with common sense to the varying circumstances of individual companies.

\section{Methodology}

The methodology adopted for this study is literature review. A literature review research, as a process, is a systematic, explicit, and reproducible method for identifying, evaluating and synthesizing the existing body of completed and recorded work produced by researchers, scholars and practitioners (Fink, 2010). A literature review is a critical analysis of information that has been published on a specific topic, and provides an organised assessment of the information put forward by various researchers on the topic. The researcher adopted this method because a review of published works in a specific area (in this case, challenges that face SMEs in Ghana) 
gives a wider perspective than a single research project can achieve.

In order to get a better view of the corporate governance challenges facing SMEs in Ghana, the researcher accessed articles on this perspective by searching in Google Scholar; key words used for the search were: SMEs, Challenges with SMEs, and SMEs in Ghana. A variety of scholarly articles came up, a total of 40 articles were accessed, but for the purpose of this work, only 15 of them were reviewed as they specifically dealt with the challenges facing SMEs in Ghana. The rest of the articles, even though, contained the desired data, were not specific to the needs of this work. The rejected articles were still used in the literature review segment of this paper as they presented a wider view of the subject under study; touching on the same issue in Africa and across the world.

The general challenges facing all SMEs in Ghana in were first reviewed, and those that had specific implications for Corporate Governance were pointed out. The researcher went on draw conclusions on what these mean for corporate governance, and then made recommendations on how a code of corporate governance specific to SMEs can help mitigate some of these challenges.

\section{Results}

\subsection{Challenges Facing SMEs in Ghana}

Researchers in this area presented findings on various challenges that confront SMEs in Ghana that are potentially crippling and can end the lives of these enterprises. This author can best classify these identified challenges into internal and external factors.

\subsubsection{Internal Challenges}

In a survey of SMEs (with a focus on foundries) in the Kumasi and Tema Metropolis, Andrew and Gikunoo (2011) found that internal challenges bedeviling SMEs include: lack of knowledge on how to source for funding, no accounting skills leading to improper bookkeeping and hence poor financial management, and they did not have documented process to evaluate, review and select suppliers for their raw materials. A study by Sarpong (2012) in the Secondi-Takoradi Metropolis revealed that owners of SMEs depend on their savings or borrowing from their friends and relatives as the main source of financing, in view of the fact that credit from the formal banking system to the informal sector is very limited. Kwaning, Nyantakyi, and Kyereh (2015) found that most managers of SMEs do not understand how interest rates are calculated; hence they go in for loans with high interest rates that they cannot afford to pay back. This finding is supported by Donkor (2012) who opines that microfinance institutions are doing a good job by providing loan facilities for SMEs, but they sometimes do not tell the truth. Some of these institutions take advantage of the educational level of SME owners, and for one reason or the other, refuse to give details and explain the interest rates and its implications on the loans to small business owners. The effect is realized when they begin the repayment of the loan.

Kwaning et al. (2015) further realized that SMEs are unable to meet the banks requirement. Most SMEs fail to obtain guarantors and collateral required by the banks, some also fail to prepare financial statements of their businesses and as such, being denied of loans. The result is in line with ECA (2001) which states that banks and other financial institutions have no confidence in

SMEs as they are perceived as high-risk ventures with high rates of failure. As a result, prohibitive collateral conditions are set up to prevent SMEs from obtaining loans, and that most guarantors are not willing to offer support due to the nature and management style of the SMEs. Kwaning et al. (2015) found that there were only $3.83 \%$ of the respondents who faced the challenge of cash flow and $1.09 \%$ faced with other challenges such as lack of business plan. Other typical internal issues identified by Kwaning et al. (2015) are poor record keeping (supported by Sarpong, 2012), giving false information to banks, and sole proprietors not keeping a separate account for the business they operate. Anane, Cobbinah and Manu (2013) also found that most SMEs were unwilling to give data on earnings and productivity. These are challenges that will pose a difficulty for any bank or financial institution that may want to lend money to such businesses.

Sarpong (2012) further found that the major internal challenges facing SMEs include: poor infrastructure, poor finishing, poor management, and lack of qualified service providers. In their study of SMEs in Accra, Ocloo, Akaba, and Worwui-Brown (2014) found that poor infrastructure, insufficient marketing knowledge, access to finance, lack of managerial skills, equipment and technology were factors hampering the growth of SMEs. Similarly, Abor and Qartey (2010) established that lack of managerial skills, equipment and technology are impediments to SME growth. 


\subsubsection{External Challenges}

Kwaning et al. (2015) in their study found access to credit as the major constraint to the growth of SMEs, followed by competition, cost of technology, and irregular power supply also constrained their growth. This result reinforces the theory by Cuevas et al. (1993) who indicated that access to bank credit by SMEs has been an issue and continues to be raised by numerous studies as a major constraint to growth, which was also supported by Aryeetey, Baah-Nuakoh, Duggleby, Hetting, and Steel (1994) who posited that from the view point of the private sector, problems related to finance dominate all other constraints to business expansion. Andrew and Gikunoo (2011) also found that Government did not support SMEs financially, access to raw materials, and credit remain the most nagging issues faced by SMEs.

Ahiabor (2013) points out that the microfinance institutions do not care about the finances of SME's but grants loans to them when they think the SME has enough collateral to secure the loan. For that matter they do not provide any financial advice and monitoring to their customers. Conducting their study in the Jaman District in the Brong Ahafo Region, Anane, Cobbinah, and Manu (2013) found that the principal challenges facing SMEs include difficulty in accessing start up capital, stringent credit conditionalities, high interest rates on credit, and inadequate government support for SMEs. The above challenges, according to the owners of SMEs, have become a barrier to the development and sustainability of their businesses.

Sarpong (2012) found High rate of importation of foreign goods, lack of access to capital, high tariffs rate, high interest rate (cost of capital). Ocloo et al., 2014) revealed that that unfavorable government policies and regulations, changing technology, increased competition, affected their business highly. Oppong, Owirendu, and Churchille (2014) indicate that lack of capital, high cost of procuring operational equipment and facilities, lack of financial support from the government and financial institutions, irregular supply of raw materials are factors militating against the growth of SMEs in Ghana. Abor and Quartey (2010) add that access to capital, high cost of technology, the regulatory environment, and little access to international partners. They also identified factors such as high taxes, competition, and high utility tariffs as other constraints facing SMEs.

Akar and Vuvor (2011) discovered among all the problems faced by SMEs in their operation ranging from competition, high utility tariffs, infrastructure among others, the participant SMEs saw the lack of credit facilities as the major constraint.

\section{Discussions}

Most of the findings by the various authors border on issues of internal concern that need urgent attention. Lack of knowledge on how to source for funds to run the businesses they set up, this is evident as most of the researchers have discovered that the owners and/or managers of SMEs in Ghana have little formal education and, in most occasions, no financial training at all. These deficiencies result in poor transaction record keeping, poor financial management, and improper documentary of business processes. These business managers do not see the need to engage professionals to prepare accounts for them, and yet, there are those who do not even the need to keep a separate account for business, and only treat the money that comes from the business as if it were their pocket money. Little wonder some banks and financial institutions are not willing to give credit to SMEs to expand; the potential lenders see these SMEs as high risk customers, and indeed they are because most of them do not understand the terms attached to such loans and default in payments.

A worrying trend is the lack of expertise among SMEs; most of the owners only set them up as a source of income for the family, they neither have any formal training on business management nor hire such expertise. The result of this the evidence of businesses not having business plans, giving false information to potential lenders, and the unwillingness to give out information on earnings and productivity. Other evidence of this deficiency are poor finishing of products (for those who manufacture), insufficient market knowledge, and losing out of the competition. Most of these entrepreneurs have not formally documented their business processes, leading to frequent shortage of raw materials, poor quality products, and complaints of irregular of supply of raw materials. This also accounts for noncompetitiveness of the local SMEs as against imported products.

External issues within the business environment of the company also issues that threaten the survival of SMEs, and they hit some of the SMEs so hard that they make losses and sometimes fold up. Some of these factors identified by various researchers are competition, cost of technology, and irregular power supply also constrained their growth. Most SMEs lack a competitive edge, especially against foreign competitors, due largely to some of the internal lapses identified earlier. High cost of technology for manufacturing and customer service is a major barrier to SME growth; the owners are not able to afford the needed equipment due mainly to the lack of access to credit. A critical look at the issues arising within the internal ambits of the SMEs shows that banks and other lending institutions are not willing to lend to these enterprises due to the internal lapses of the 
SMEs themselves.

Lack of government support for SMEs has also come out strongly. The government over the years has made some interventions directly and indirectly to encourage entrepreneurship but SME owners who were interviewed by various researchers did not recognize any form of government intervention. It could be that they are either not aware of such interventions or are not able to access them. Access to credits facilities is a thorny issue that cut across all the SMEs research; the lending institutions charge high interest rates, there are stringent conditions attached, and sometimes they demand the kind of collateral that does not come easy to these SMEs. Again, this begs the question of the internal affairs of the enterprises, the lenders see them as high risk customers, and would like to take every step to ensure that their investments do not go waste.

Unfavorable government policies and regulations also come up very strongly as some of those factors militating against the growth of SMEs in Ghana. Regulations concerning taxes, registration requirements, and other legal requirements are sometimes so stringent that SMEs are not able to cope with. Value Added Tax, withholding taxes, and local authority levies have been viewed by SMEs as having a negative impact on their businesses; they think these taxes erode their gains leave without any profits. Another nagging issue that gets a lot of prominence in this regard is high tariffs that the SMEs have to pay to access utilities (electricity and water), most SMEs use electricity in their business processes. High utility bills hurt profit margins, and, in some cases is the major element of the total cost of production. These taxes and tariffs make the average cost of a product so much that the producer has to pass them to the consumer, consumers also see these prices as exorbitant, thereby leading to low demand and most importantly, they lose out of competition especially, from foreign competitors.

It is the opinion of this author that the challenges that face SMEs in Ghana, as identified above, can be mitigated by a set of comprehensive guidelines embedded in a code of corporate governance meant purposely for SMEs. This confirms the views of Bundaleska et al. (2011) and Dube et al. (2011), who suggest the need for a set of guidelines for the governance of SMEs. Most of the internal challenges found by researchers concern administrative lapses such as poor management skills, lack of expertise, poor record keeping, lack of understanding of the market among others. These challenges can properly be taken care of by corporate governance regulations. The regulations will help in enforcing some these basic requirements for conducting business before they can be duly recognized by the appropriate regulatory and supervisory bodies. The lack of access to credit is due mainly to these internal lapses; the business processes are not properly documented, accounts are not prepared according to standard practice if any at all, most of the owners/managers do not have any understanding of how the business should run as a separate entity. The potential lenders generally see these SMEs as high risk customers and, rightly so, they do not see these SMEs worth investing in.

Corporate governance regulations will also ensure that the right persons are engaged in directing the affairs of SMEs. These persons will have the knowhow to manage the effect of external factors such as taxation, other legal requirements, and sourcing for funds for business growth. The SMEs will possess, or at least have access to, experts who can advise them on how to take advantage of tax credit reliefs, pay withholding taxes and still maintain their profitability, and fulfill other requirements that SMEs see as too cumbersome for them to go through. As stated earlier, complaints of lack of government support could mean either they are not aware of government interventions or have no idea how to access it. Governance regulations will help them put in place measures and people who can help them access some of these interventions.

\section{Conclusion}

Small and Medium Scale Enterprises (SMEs) constitute a large chunk of businesses in Ghana, account for about 92 per cent of businesses in Ghana (Abor \& Adjasi, 2007), contributing to GDP growth, and are practically, a bedrock of the economy. They are located in almost all sectors of the economy, and are also a source of income to most families in the country. Unfortunately, these small businesses face challenges in both the internal and external environments which threaten their very survival and growth. Most researchers in this regard have found that the most common challenges small businesses face in Ghana include lack of expertise in business and financial management, poor record keeping, lack of planning, no access to credit, and government regulations that do not favor the growth of SMEs.

Following the above findings, the researcher recommends that there must be a conscious effort to develop and enact a code of corporate governance meant specifically for SMEs in Ghana. This author recommends that such a code should contain the following subject matters:

i. The structure and succession plan of the business

ii. Appointment of directors and their emoluments 


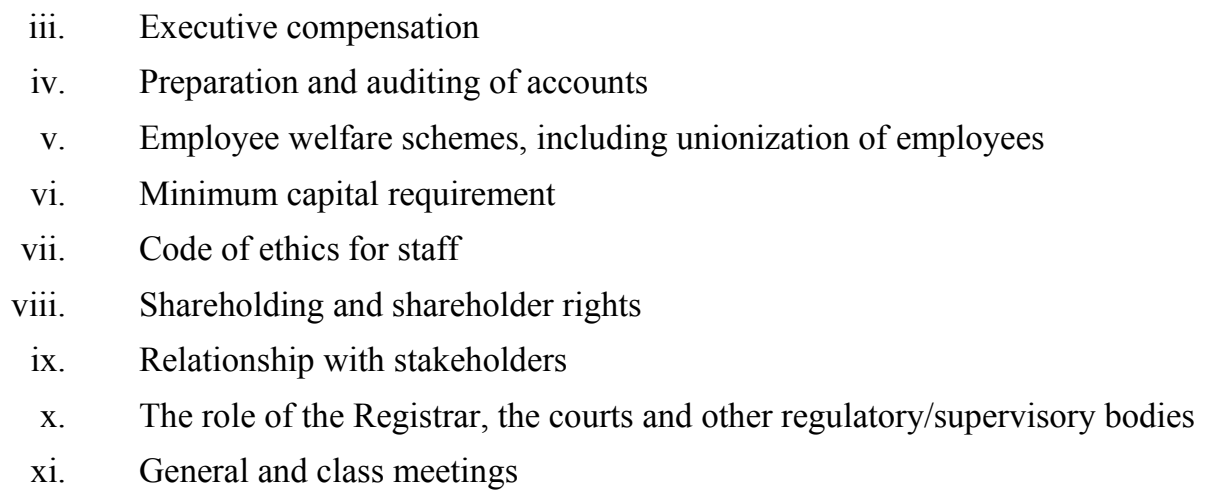

Claessens (2003) is of the opinion that better corporate frameworks benefit firms through greater access to financing, lower cost of capital, better performance and more favourable treatment of all stakeholders. Therefore, a code in this nature will be a very good intervention to make SMEs better managed, more accountable, and credit worthy.

\section{References}

Abor, J., \& Adjasi, C. K. D. (2007). Corporate Governance and the small and medium enterprises sector: Theory and implications. Corporate Governance: International Journal of Business in Society, 7(2), 111-22.

Abor, J., \& Quartey, P. (2010). Issues in SME Development in Ghana and South Africa. International Research Journal of Finance and Economics, 39, 218-228.

ACCA (2015) Corporate Governance for All: Implementation challenges for SMEs. Retrieved from http://www.accaglobal.com/globalforums. Accessed 20 December 2016

Ackah, J., \& Vuvor, S. (2011) The Challenges faced by Small \& Medium Enterprises (SMEs) in Obtaining Credit in Ghana. Independent thesis Advanced level (degree of Master (One Year)) Student thesis, Blekinge Institute of Technology, School of Management.

Adjei, L. N., Oteng, E., \& Fianu, A. (2014). Accounting practices and control systems of SMEs: A case study of Techiman municipality. Journal of Finance and Accounting, 2(3), 30-40.

Ahiabor, G. (2013). The Impact of Microfinance on the Development of Small Scale Enterprises in the Greater Accra Region of Ghana. European Journal of Business and Management, 5(7), 165-171.

Anane, G. K., Cobbinah, P. B., \& Manu, J. K. (2013). Sustainability of Small and Medium Scale Enterprises in Rural Ghana: The Role of Microfinance Institutions. Asian Economic and Financial Review, 3(8), 1003-1017.

Andrews, A., \& Gikunoo, E. (2011). Small Scale Foundries in Ghana: The Challenges. Leonardo Electronic Journal of Practices and Technologies, 1-12.

Aryeetey, E. A., Baah-Nuakoh, T., Duggleby, H. H., \& Steel, W. F. (1994). Supply and demand for finance of small Scale enterprises in Ghana, Discussionpaper No. 251, World Bank, Washington, DC.

Aryeety, E. (2001). Priority Research Issues Relating to Regulation and Competition in Ghana. Centre for Regulation and Competition Working Paper Series. (Paper No.10).

Baumol, W. J. (2004). Education for Innovation: Entrepreneurial Breakthroughs vs. Corporate Incremental Improvements. Working Paper 10578. Retrieved from http://www.nber.org/papers/w10578

Berglog, E., \& Ernst-Ludwig, V. T. (1999). The Changing Corporate Governance Paradigm: Implications for Transition and Developing Countries, Conferences Paper, Annual World Bank Conference on Development Economics, Washington D.C.

Bundaleska, E., Dimitrova, M., \& Nikolovska, Z. (2011). Corporate Governance and Small \& Medium Businesses. Munich Personal RePEC Archive.

Cadbury, A. (1992). Report of the Committee on the Financial Aspects of Corporate Governance. Gee Publishing, London.

Carsamer, E. (2009). Access To Credit by SMEs in Ghana:Does the type of business matter? Social Science Today. Winneba: Jim Waler Light and Salt Publishers.

Cuevas, C., Fafchamps M., Hanson R., Molland, P., \& Srivastava P. (1993). Case Studies of Enterprise Finance in 
Ghana. Final report, Regional Program on Enterprise Development, The World Bank.

Culkin, N., \& Smith, D. (2000). An Emotional Business: A Guide to Understanding the Motivations of Small Business Decision Takers. Qualitative Market Research, 3(3), 145-157.

Curran J. (2000). What is small business policy in the UK for? Evaluation and assessing small business policies. International Small Business Journal, 18(3), 36-51. https://doi.org/10.1177/0266242600183002

Donaldson, W. H. (2003). Corporate Governance. Business Economics, 38, 16-20.

Donkor, K. (2012). Financial illiteracy dilemma, Business guide. Retrieved on 24 October 2012 enterprises sector: theory and implications. Corporate governance, 7(2).

Dube I., Dube D., \& Mishra P. (2011) Corporate Governance Norm for SME. Journal of Public Administration and Governance, 1(2).

ECA. (2001). Enhancing the competitiveness of small and medium enterprises in Africa: a strategic framework for institutional support. http://repository.uneca.org/handle/10855/3324

EcoDa (2010), Corporate Governance Guidance and Principles for Unlisted Companies in Europe. http://ecoda.org/uploads/media/ GUIDANCE_-_2010_CG_for_Unlisted_-_EU.pdf

Feeney, L. S., \& Riding, A. L. (1997). Business Owners' Fundamental Tradeoff: Finance and the Vicious Circle of Growth and Control, Canadian Business Owner, November.

Fink, A. (2010). Conducting Research Literature Review: from the Internet to Paper (3rd ed.). Sage Publications.

Hong Kong Institute of Directors. (2014). Guidelines on Corporate Governance for SMEs in Hong Kong (3rd ed.). http://www.hkiod. com/sme-guidelines.html

Jill, S., \& Aris, S. (2010). Corporate Governance and Accountability. John Wiley \& Sons Ltd, Chichester, England. (p. 14)

Kwaning, C. O., Nyantakyi, K., \& Kyereh, B. (2015). The Challenges Behind SMEs' Access to Debts Financing in the Ghanaian Financial Market. International Journal of Small Business and Entrepreneurship Research, 3(2), 16-30.

Kyereboah-Coleman, A., \& Amidu, A. (2008). The Link Between Small Business Governance and Performance: The Case of the Ghanaian SME Sector. Journal of African Business.

Kyereboah-Coleman, A., \& Biekpe, N. (2005). Corporate Governance and the performance of Microfinance Institutions (MFIs) in Ghana. Working paper, UGBS, Legon.

Lokhande, M. (2011). Financial inclusion: options for micro, small and medium enterprises. Synergy. 9(2), $39-50$.

Maharaj, A. (2011, January 4). Corporate governance and small businesses. http://www.corporatesecretary.com/articles/boardrooms/corporate-governance-small-business/11483

Mensah, S. (2004). A Review of SME Financing Schemes in Ghana. A Presentation at the UNIDO Regional.

National Board for Small Scale Industries. (2005). Newsletter, Vol. 1, No. 8, BPP Publisher, December.

Ntim, A. L., Oteng, E., \& Fianu, A. (2014). Accounting Practices and Control Systems of Small and Medium Size Entities: A Case Study of Techiman Municipality. Journal of Finance and Accounting, 2(3), 30-40.

Ocloo, C. E., Akaba, S., \& Worwui-Brown, D. K. (2014). Globalization and Competitiveness: Challenges of Small and Medium Enterprises (SMEs) in Accra, Ghana. International Journal of Business and Social Science. 5(4).

OECD. (2004). OECD Principles of Corporate Governance Retrieved from http://www.oecd.org/daf/ca/corporategovernanceprinciples/31557724

Oppong, M., Owirendu, A., \& Churchille, R. Q. (2014). Micro and Small Scale Development in Ghana. European Journal of Accounting Auditing and Finance Research, 2(6), 84-97.

Quartey, P., \& Abor, J. (2010). Issues in SME development in Ghana and south africa. International Research Journal of Finance and Economics, 39. http//www.eurojournals.com/finance.htm/50746389

Rahman, S. (2001). A comparative study of TQM practice and organisational performance of SMEs with and without ISO 9000 certification. International Journal of Quality \& Reliability Management, 18(1), 35-49. 
Sarpong, D. A. (2012). Micro, small and medium scale enterprises in Ghana: challenges and prospects. A case study of sekondi-takoradi metropolis. Masters Degree thesis, Kwame Nkrumah University of Science and Technology.

SME Dubai and Hawkamah. (2011). The Corporate Governance Code For Small and Medium Enterprises: Building the Foundations for Growth and Sustainability.

Steel, W. F., \& Webster, L. M. (1991). Small Enterprises in Ghana: Responses to Adjustment. Industry Series Paper, No. 33, The World Bank Industry and Energy Department, Washington.

Tsamenyi, M., Enninful, E., \& Onumah, J. (2007). Disclosure and corporate governance in developing countries: evidence from Ghana. Managerial Auditing Journal, 22(3), 319-334.

\section{Copyrights}

Copyright for this article is retained by the author(s), with first publication rights granted to the journal.

This is an open-access article distributed under the terms and conditions of the Creative Commons Attribution license (http://creativecommons.org/licenses/by/4.0/). 